\title{
Does Learner-Centred Approach Improve High School Learners' Understanding of Acids and Bases Topic? A Case of Two Selected Secondary Schools in Ohangwena Region, Namibia
}

\author{
Sanio I. T. Mutilifa1, Hileni M. Kapenda² \\ ${ }^{1}$ Ministry of Education Arts \& Culture, Eenhana, Namibia \\ ${ }^{2}$ University of Namibia, Windhoek, Namibia \\ Email: faitthsanjoh30@gmail.com,hkapenda@unam.na
}

How to cite this paper: Mutilifa, S. I. T., \& Kapenda, H. M. (2017). Does Learner-Centred Approach Improve High School Learners' Understanding of Acids and Bases Topic? A Case of Two Selected Secondary Schools in Ohangwena Region, Namibia. Creative Education, 8, 1260-1274. https://doi.org/10.4236/ce.2017.88089

Received: May 9, 2017

Accepted: July 10, 2017

Published: July 13, 2017

Copyright $\odot 2017$ by authors and Scientific Research Publishing Inc. This work is licensed under the Creative Commons Attribution International License (CC BY 4.0).

http://creativecommons.org/licenses/by/4.0/

\begin{abstract}
This paper presents findings on a study that was conducted at two selected secondary schools in Ohangwena educational region in Namibia. The study used a quantitative approach to investigate if using learner-centred approach improves learners' understanding of acids and bases. With a sample of 80 grade 11 learners taking Physical Science Ordinary level, a quasi-experimental design was used to collect data from two schools for two weeks (one week at each school). The Pre-test, post-test scores from the control group consisting of 40 learners from school A and an experimental group of 40 learners from school $\mathrm{B}$ were used to establish the cause and effect relationship between the use of Learner-Centred Approach (LCA) and learners' understanding of acids and bases based on their performance in the tests were given. Descriptive statistics was used to analyse the quantitative data from the tests cores and a t-test analysis was conducted for both groups. The study results indicated that the experimental group performed better than the control group. It also emerged that using various learner-centred activities attracted learners' interests in learning and understanding acids and bases. It is therefore concluded that learner-centred approaches improved high school learners' understanding of the topic acids and bases. The study recommends that Physical Science teachers should make the teaching and learning of acids and bases more practical-based by using learner-centred approaches.
\end{abstract}

\section{Keywords}

Learner-Centred Approach, Physical Science, Effectiveness, Acids and Bases, Teaching and Learning, Social Constructivism, High School Learners, Namibia 


\section{Introduction}

Like many other post-independent African countries, Namibia went through many changes after independence, politically, socially and educationally, as the nation sought to determine its own destiny. Therefore, immediately after independence, the Ministry of Education and Culture (MEC, 1993) articulated four major goals of education as access, equity, quality and democracy and it states that, "As we make transition from educating the elite to education for all we also make a shift from teacher-centred to learner-centred" (p. 74). In South Africa, Khoboli (2007) indicated that the education policy change is more about paradigm shifts, not only in the practices and documentation but also in personal and public knowledge of teachers. The trends of changing from a traditional (teacher-centred) approach to a learner-centred one are observed in some Southern African countries, namely, Botswana, Lesotho, South Africa and Namibia (Khoboli, 2007). In fact, Lattimer (2015: p. 65) stated that "for more than three decades national governments and international donor agencies have worked to improve elementary and secondary education in sub-Sahara Africa by encouraging the adoption of learner-centred pedagogies". In independent Namibia, education transformation is worth examined, since it deals with the change from teacher-centred to learner-centred teaching approaches. Hence, it is against this background that the MEC (1993) proposed learner-centred-teaching methods for basic education in Namibia.

Internationally, studies in Turkey have shown that learners usually have difficulties understanding the concepts of acids and bases. Cros, Amouroux, Leber, \& Fayor (2006) reported that university students tended to use descriptive definitions rather than terms of proton transfer, whereas Nakhleh \& Krajcik (2004) found that secondary school learners on the North coast of Black Sea Region had difficulties identifying acid and base colours on the $\mathrm{pH}$ scale. The concern about the quality of teaching and learning in science classrooms is a global issue, but particularly so in developing countries, such as Namibia. According to Qhobela \& Moru (2011), these concerns include dominance of teacher-centred lessons and under use of experimentation, compelling researchers and educators to pursue a variety of options to address them. Various researchers (Beaten, Kyndt, Struyven \& Dochy, 2010; Lattimer, 2015; Marioara, 2015; Boyadzhieva, 2016) have argued for more learner-centred teaching and learning environment than traditional teacher-centred approaches. For instance, Boyle \& While (2004) have argued that:

... approaches such as study groups in which teachers are engaged on regular, structured and collaborative interactions around topics of concerns identified by the group are more likely to make a positive impact on their practice than traditional approaches such as question and answer used in teacher-centred approach (p. 47).

Physical Science is a practical subject that is amenable to the use of the learner-centred approach (LCA) to teaching with learners playing active roles in 
the teaching and learning process (Doyle, 2008). Biggs (1999) identified "learner activity and 'interaction with others' as two of four factors likely to encourage a leaner-centred approach to teaching" (p. 73); whilst Ramsden (1992) believes that learner-centred is "encouraged by teaching and assessment methods that foster active and long-term engagement with learning tasks" (p. 81). Progress towards better achievement of Physical Science high school learners in the Ohangwena region has been slow. According to the Namibian annual examiners' report for Physical Science Ordinary level (Directorate of National Examinations and Assessments [DNEA], 2013), "acids and bases" is a topic identified as being consistently badly performed and the statistics on the components of the three papers (in the Namibia Senior Secondary Certificate Ordinary Physical Science examination) written in 2013 indicated that about 58 percentages of learners failed the questions on acids and bases (DNEA, 2013). Therefore, this study investigated the effectiveness of learner-centred approaches in teaching and learning acids and bases in two selected secondary schools in the Ohangwena educational region by testing the following hypotheses: $\mathrm{H}_{0}$-there is no significant difference in learners' performance in acids and bases topics when taught using the learner-centred approach. $\mathrm{H}_{1}$-there is a significant difference in learners' performance in acids and bases topics when taught using the learner-centred approach.

\section{Theoretical Framework and Literature Review}

This study was informed by the theory of social constructivism developed by Vygotsky (1978) as:

"the social contexts of learning and that knowledge is mutually built and constructed. By interacting with others, students get the opportunity to share their views and thus generate a shared understanding related to the concept" (Kalpana, 2014: p. 28).

According to Gray (1997), constructivist teaching is based on a belief that learning occurs as learners are actively involved in a process of meaning and knowledge construction as opposed to passively receiving information. Learners are the makers of meaning and knowledge. For Gray (1997), “Constructivist teaching fosters critical thinking, and creates motivated and independent learners" (p. 7). Similarly, Atherton (2013) places the emphasis of social constructivism on the learner as an active "maker of meanings" while the role of the teacher is to enter into a dialogue with the learner, trying to share the meaning of the material to be learned, and to help her or him refine an understanding until it corresponds with that of the teacher. Constructivist classrooms are structured so that learners are immersed in experiences within which they may engage in meaning-making inquiry, action, imagination, invention, interaction, hypothesising and personal reflection (Gray, 1997). For Risse (2004), producing a democratic classroom environment provides meaningful learning experiences for autonomous learners. Therefore, constructivism requires a student-centred 
classroom and involves a constructivist student-centred approach which places more focus on students learning than on teachers teaching (Kalpana, 2014).

Other qualities of a constructivist classroom are democratic and have an interactive nature, as highlighted by Gray (1997), for whom a democratic classroom environment emphasises shared responsibility and decision-making. It is also argued by various scholars that practices which typify democratic classrooms include acknowledgement of the importance of human experience in learning; accommodation of small groups, individuals, and, occasionally, the whole class in instruction; creation of an environment that supports the active involvement of students in collaborative and empowering activities such as the exchange of ideas and opinions, and responsibility for making decisions about learning and for generating flexible rules; and teacher focus on students' learning rather than on teacher performance (Lester \& Onore, 1990; McNeil, 1986). Taber (2011) also argues that an interactive student-student and student-teacher dialogue is important in a constructivist classroom.

\subsection{Definition of Learner-Centred Approach}

According to Lattimer (2015: p. 66), the concept "learner-centred educational approaches have been a core feature of both national and international educational policy discussions in sub-Sahara Africa for more than two decades". The changes in the education system, especially with the emergence of online schooling, has led to many controversies as stakeholders argue about approaches that are most efficient and effective (Al-Zu'be, 2013). Among these is one between the learner-centred and teacher-centred approaches to education (Froyd, \& Simpson, 2008). The two approaches may be defined as follows:

Leaner-centred approach is defined as an approach to the teaching and learning process which supports the concepts of a learner as an active participant and supports the instructor's additional competencies as mediator and facilitator of learning through learner support techniques and practices (Weimer, 2002). While, teacher-centred approach is an approach that portrays learners as basically passive while the teachers are active since teachers are the main focus in this approach which is considered sensible since the teachers are familiar with the language which the learners are not. In this case, the students are less engaged during the learning process (Al-Zu'be, 2013).

Qhobela \& Moru (2011) describe the term learner-centred as a practice in which the learners and the teacher learn from one another. It is an active learning process by which learners are actively involved in the classroom. In this study, the term learner-centred approaches refer to the methods of teaching that involve active participation of learners in Physical Science lessons through sharing experiences with hands-on activities, laboratory practices, outdoor practices, small-group discussions and observatory activities, in particular to enable them to learn the topic Acids and bases in a more learner-centred way. Therefore, active learning, student engagement and other strategies that involve students and mention learning are called "learner-centred" (Murphy-Graham, 2008). In ad- 
vocating "The education change for in need student-centred learning", Marioara (2015) stated that learner-centred paradigm is an approach where students construct knowledge and understanding based on what they already know and/or believe; they formulate new knowledge by modifying and refining their current concepts and adding new concepts to what already known. Similarly, Froyd \& Simpson (2008) argue that a learner-centred approach is an instructional approach in which learners influence the content, activities, materials, and pace of learning; hence this model places the learner at the centre of the learning process. Accordingly, Hua, Harris, \& Ollin (2011) see the teacher's role as providing learners with opportunities to learn independently and from one another, and to coach them in the skills they need to do so effectively. Learner-centred education (LCE) includes techniques such as substituting active learning experiences for lectures; assigning open-ended problems and ones that require critical or creative thinking that cannot be solved by following text examples; involving learners in simulations and role plays; and using self-paced and/or cooperative (team-based) learning (Al-Zu'be, 2013). If it is properly implemented, LCE can lead to increased motivation to learn, greater retention of knowledge, deeper understanding, and more positive attitudes towards the subject being taught (Froyd \& Simpson, 2008).

\subsection{Teaching and Learning Methods of Learner-Centred Education}

A number of methods are associated with learner-centred education (Brandes \& Ginnis, 1996; Bruce \& Marsha, 1996; Dunne \& Wragg, 1997), but no single one is superior, particularly in terms of student performance. Accordingly, Savelsbergh, Prins, Rietbergen, Fechner, Vaessen et al. (2016) noted that many teaching approaches that foster positive attitudes toward science and mathematics have been proposed over the past decades. Consequently, in learner-centred education, methods of teaching must be matched to the objectives and intended tasks for efficiency and effectiveness. In the context of this study, some learner-centred methods which are mostly relevant to the teaching and learning of science, particularly Physical Science, are discussed below:

Collaborative and cooperative learning teaching approaches such as project-based work, discussion and peer feedback tend to enhance social interaction and make learners relate to one another more easily (Savelsbergh, Prins, Rietbergen et al., 2016). These teaching methods are appropriate for use, specifically in science-related subjects because learners could discuss abstracts concepts among themselves and as such get involved in increased ownership of the content to be learnt by sharing ideas.

Practicals and Experimentation are important components of coursework and practical work in Physical Science (Kagan, 1995; Dunne \& Wragg, 1997). For example, in Experimental techniques, learners are required to use the appropriate apparatus for the measurement of time, temperature, mass and volume under the guidance of their teacher. In learning the topic "Acids and bases" learners are expected to use indicators (paper or solution) for different reagents to 
determine their $\mathrm{pH}$ values in relation to the colour change. Learners can also carry out reactions of acids with metals, metal carbonates and with bases. Learners can do the work individually or as a group. The purpose of an experimentation method of teaching is usually to help the learners to make a discovery, test a theory or demonstrate known claims by undertaking a scientific procedure. This method of teaching can help learners to try out new things practically, thus gaining a better insight into the learning content (Katz, 1990). Johnson \& McCoy (2011) confirmed that when students discover new evidence during experiments it gives them positive attitudes towards investigations and experimentations in the science classroom.

Group Work is a technique that uses interactions between learners as part of the learning process. Students are usually divided into groups of three or four, depending on the size of the class. The groups are assigned to specific tasks to perform under the supervision of the teacher. Group work gives learners the opportunity to work together (Brandes \& Ginnis, 1996; Dunne \& Wragg, 1997; Cullingford, 1998) and important social skills are developed as well as what is being learnt through the work the group is doing. The teachers can use this technique to share understanding about an issue through facilitating discussion in groups. They are involved in the process of helping learners to develop skills of finding information, though group work the learners would also seek help or information from each other. Once learners are involved, they show their eagerness to share to others what they experience and this could lead to new connections that support understanding (Maioara, 2015). The teacher here takes the role of facilitator, either as a participant in the group or as an outsider, almost in a consultant's role (Johnson, Johnson, \& Holubec, 1993; Brandes \& Ginnis, 1996; Imasiku, 1999). Group work is a substantial pillar of learner-centred education and its potential contribution to more effective learning and more confident learners and teachers is significant if it can be carried out well. Responsibilities are shared among members of the group and, as such, students become accountable for their own learning and that of others (Kagan, 1995; Brandes \& Ginnis, 1996; Engelbrecht, 2000). According to Hailikari, Katajavuori, \& Lindblom-Ylanne (2008), when learners work in groups they are accountable for each other's learning as their prior knowledge in the topic influences their performance and that of their peers.

Small-group discussions are emphasised in social constructivist learning theory, with group interaction seen as a major contribution to sense-making (Driver, Guesne, \& Tiberghien, 1985). The use of small-group discussions is supported by a specific programme that fostered collaborative reasoning including evaluating and strengthening of knowledge claims, improved learners' metacognitive knowledge of collaborative reasoning, including their knowledge of reasoning about evidence. However, the improvement in collaborative reasoning depended on learners' perspective on learning, and learners with a learner-as-explorer perspective gained significantly more than peers with a learner-as-student perspective (Hogan, 1999). Within the Southern Africa De- 
veloping Countries (SADC) region and elsewhere, policymakers continue to promote learner-centred teaching approaches (e.g., MEC Namibia, 1993; Department of Education, South Africa, 2014) and active learning strategies (Kyriacou, Manowe, \& Newson, 1999). In both policies and studies, discussions in small groups are advocated as important ways of implementing learner-centred approaches in classrooms. Bennett, Lubben, Horgarth, \& Campell's (2004) study on a systematic review of the role of small-group discussions in science teaching provided a synthesis of the outcomes of research on small-group discussions for improving learners' understanding of evidence in science.

Simulations enable learners to provoke a scaled-down estimate of a real-life situation, and allows accurate practice without the cost or the risks otherwise involved (Gredler, 1996). Simulations may involve participant dialogue, manipulation of materials and equipment, or interaction with a computer. Laboratory experiments in Physical Science are popular topics for simulations (Jones, 1985), and provide practice in specific skills. Although simulations may produce anxiety for some learners they help most to actively participate in the teaching and learning process; they can be used for acquisition of information, improvement of new processes, and identification of alternatives in decision-making. They can build positive values and attitudes in learners (Jones, 1985), and as Kolb's theory of experiential learning posits, they also plays a role in transformation of knowledge (Kolb, 1984), Hence, simulations can be referred to as experiential exercises because they provide unique opportunities for students to interact with a knowledge realm.

Field trips are the logical extension of bringing part of the world into the classroom, thus in turn taking the class into the "real world". They are useful not only because they give learners first-hand knowledge and enable them to see how a number of skills, processes, blend into a whole, but also because they can be used to provide learners with cultural experiences available in no other way. Field trips should be directly related to a continuing unit of work and learner involvement during each step of planning one helps generate interest and makes them more worthwhile (McCombs \& Whistler, 1997; Engelbrecht, 2000). Accordingly, Physical Science teachers are required to use different learner-centred methods of teaching in their classrooms to meet the demands of the syllabus and to address the needs of the different capabilities of the individual learners.

\section{Research Methodology}

This study employed a quantitative research approach and a quasi-experimental design was used to investigate the effectiveness of learner-centred approaches in teaching and learning acids and bases at the two selected secondary schools in Ohangwena educational region in Namibia. A sample of 80 Grade 11 learners studying Physical Science at Ordinary level was randomly selected from the two secondary schools to avoid data contamination. From this sample, 40 learners were selected from school A and belonged to a control group while the other 40 learners were selected from school B and they were used as an experimental 
group. In this study, the same pre-test was given to both the control and experimental groups on the first day as both learners were on similar levels of understanding in relation to the topic of Acids and bases. One of the researchers taught both groups as an intervention. During these teaching lessons, the learners in the experimental group were presented with hands-on activities and laboratory practices such as experimentations, small-group discussions, group work and outdoor activities namely, field trips to enable them to learn the topic "acids and bases" in a more learner-centred setting. Each lesson lasted for duration of 90 minutes. On the fifth day, a post-test was administered to each group independently.

To the control group one of the researchers also explained the purpose of the study and administered a pre-test on the first day. The group was taught the same competencies on acids and bases (as the experimental group) but, using traditional teaching methods, namely, chalk and board, paper and pencil techniques, question-and-answer, and whole class discussions. The results obtained from the pre-test and post-tests of the two groups were analysed using a t-test to determine whether or not the use of various learner-centred teaching methods had a significant effect on the performance of the learners.

\section{Findings and Discussions}

The study findings are presented below. Firstly, the pre-and post-test results of both groups were analysed using descriptive analysis to determine the differences in performance before and after. Furthermore, the results of the pre-tests and post-tests of both groups were paired and a t-test was carried out to determine whether the use of various learner-centred teaching methods had a significant effect on the performance of the high school learners in understanding the topic acids and bases.

With reference to Table 1 the measures of central tendencies results, the mean scores in the experimental group for the pre-test (11.9250) and post-test (16.5000) differed by 4.5750. In Table 2 the mean scores for the control group in both the pre-test and post-test were the same (11.2000). This indicated that there

Table 1. Experimental group results.

\begin{tabular}{ccc}
\hline Statistics & Pre-test & Post-test \\
\hline Valid & 40 & 40 \\
Missing & 0 & 0 \\
Mean & 11.9250 & 16.5000 \\
Median & 12.0000 & 17.0000 \\
Mode & 11.00 & $15.00^{\mathrm{a}}$ \\
Std. deviation & 2.41138 & 2.24179 \\
Variance & 5.815 & 5.026 \\
Range & 12.00 & 9.00 \\
Sum & 477.00 & 660.00 \\
\hline
\end{tabular}

a. Multiple modes exist. The smallest value is shown. 
was no change in learners' performances when taught using teacher-centred approaches. On the other hand, the mode scores in Table 1 (experimental group) increased from 11 in the pre-test to 15 in the post-test. This implies that more learners scored 11 out of 20 in the pre-test, while in the post-test (after the intervention) most learners scored 15 out of 20 .

Surprisingly, in Table 2 (control group) the mode score decreased from 12 in the pre-test to 11 in the post-test; which implies that most learners scored 12 out of 20 in the pre-test while in the post-test most learners scored 11 out of 20 . The sum in both the pre and post-test scores in Table 2 is the same (448.00) for the control group; while the sum in both the pre and post-test scores in Table 1 differs in the experimental group.

\subsection{Differences in Pre-Test Results of the High School Learners in the Two Selected Secondary Schools}

Table 3 shows how the pre-test scores from the two groups were paired. In order to establish the difference in performance between two groups, a t-test was carried out to determine whether two means were significantly different from each other at a given $\alpha=0.05$ level. The results in the table reveal that: $t_{\text {calculated }}$ to be 1.642 ; while the $t_{\text {critical }}$ value $=3.558$ in the table at $\alpha=0.05$ and degrees of free$\operatorname{dom}(\mathrm{df})=39$. Therefore, the $t_{\text {calculated }}=1.642$ is less than $t_{\text {critical }}=3.558$. Hence, the $\mathrm{H}_{0}$ (null hypothesis) is accepted. That is, the results indicated no significant difference in the pre-test scores between the experimental and the control group. This means, there is no difference in the mean scores of the two group pre-test results. The participants have scored the same marks in the pre-test. This indicates that, the participants had the same level of understanding at the beginning of the study. Such results reflect those of Goodwin \& Goodwin (1996), for

Table 2. Control group results.

\begin{tabular}{ccc}
\hline Statistics & Pre-test & Post-test \\
\hline $\mathrm{N}$ & 40 & 40 \\
Missing & 0 & 0 \\
Mean & 11.2000 & 11.2000 \\
Median & 11.5000 & 11.0000 \\
Mode & 12.00 & 11.00 \\
Std. deviation & 1.98972 & 1.88380 \\
Variance & 3.959 & 3.549 \\
Range & 10 & 9 \\
Sum & 448.00 & 448.00 \\
\hline
\end{tabular}

Table 3. Paired samples test: Experimental and control group pre-test scores.

\begin{tabular}{|c|c|c|c|c|c|c|c|c|}
\hline & & \multicolumn{5}{|c|}{ Paired Differences } & \multirow{3}{*}{$\mathrm{t} \quad \mathrm{df}$} & \multirow{3}{*}{$\begin{array}{c}\text { Sig. } \\
\text { (2-tailed) }\end{array}$} \\
\hline & & \multirow[t]{2}{*}{ Mean } & \multirow{2}{*}{$\begin{array}{c}\text { Std. } \\
\text { deviation }\end{array}$} & \multirow{2}{*}{$\begin{array}{l}\text { Std. } \\
\text { error mean }\end{array}$} & \multicolumn{2}{|c|}{$\begin{array}{c}95 \% \text { confidence interval } \\
\text { of the difference }\end{array}$} & & \\
\hline & & & & & Lower & Upper & & \\
\hline Pair 1 & Pre-test & 0.82500 & 3.17755 & 0.50241 & -0.19123 & 1.84123 & 1.64239 & 0.109 \\
\hline
\end{tabular}


whom, "the two comparable groups were intact classes with similar characteristics and all had the same level of understanding at the beginning of the study" (p. 145).

\subsection{Differences in Post-Test Performance of High School Learners in Two Selected Secondary Schools}

Table 4 shows how the post-test scores from the two groups were paired and in order to establish the difference in performance between the two groups, a t-test was used to determine whether the two means were significantly different from each other at a given $\alpha=0.05$ level. The results were: $\mathrm{t}_{\text {calculated }}$ equals -11.253 while the $t_{\text {critical }}$ value $=3.558$ in the table at $\alpha=0.05$ and degrees of freedom $(\mathrm{df})=$ 39. Therefore, the $t_{\text {calculated }}=-11.253$ (the sign notwithstanding) is more than $t_{\text {criti- }}$ cal $=3.558$. The $\mathrm{H}_{0}$ (Null hypothesis) is rejected and an alternative hypothesis $\left(\mathrm{H}_{1}\right)$ is accepted, which states: "There is a significant difference in the performance of the learners, when taught using learner-centred approaches". This means that the experimental group had obtained higher scores than the control group in the same post-test. We assumed that the difference in the performance was due to the intervention which was using various learner-centred teaching methods, namely group work, simulations, field trips, just to mention a few. The experimental group's understanding on acids and bases was improved since their performance in the post-test was higher than pre-test results. Moreover, Baeten et al. (2010) are of the opinion that using learner-centred learning environments stimulate deep approaches to learning provided students are intrisically motivated.

The findings in Table 4 corroborate several other research reports indicating that active learning-based teaching methods such as small-group discussions, experimentation, stimulations and outdoor activities are more effective than traditional methods (e.g., lecture method) in improving students' understanding and their academic performance (Cook \& Hazelwood, 2002; Saville, Zinn, Neef, Norman, \& Ferreri, 2006). The findings of this study also agree with those of Martins \& Oyebanji (2000) and Bajah \& Asim (2002), who found that the guided discovery approach was more effective than the conventional or other methods of students' acquisition of knowledge in teaching-learning process. One should also take into account that the students' approaches to learning in very crucial. According to Baeten et al. (2010: p. 243), "While some students made us of deep learning processes which were associated with an intention to understand, others used surface learning processes in order to reproduce the learning

Table 4. Paired samples test: Experimental and control group post-test scores.

\begin{tabular}{|c|c|c|c|c|c|c|c|c|}
\hline & & \multicolumn{5}{|c|}{ Paired differences } & \multirow{3}{*}{\multicolumn{2}{|c|}{ df $\begin{array}{c}\text { Sig. } \\
(2 \text {-tailed })\end{array}$}} \\
\hline & & \multirow{2}{*}{ Mean } & \multirow{2}{*}{$\begin{array}{c}\text { Std. } \\
\text { deviation }\end{array}$} & \multirow{2}{*}{$\begin{array}{l}\text { Std. } \\
\text { error mean }\end{array}$} & \multicolumn{2}{|c|}{$\begin{array}{l}95 \% \text { confidence interval } \\
\text { of the difference }\end{array}$} & & \\
\hline & & & & & Lower & Upper & & \\
\hline Pair 1 & Post-test & -5.45000 & 3.06301 & 0.48430 & -6.42960 & -4.47040 & -11.25339 & 0.000 \\
\hline
\end{tabular}


materials. This combination of intention and related processes was called an approach to learning". The emphasis here is to take cognizance of the fact that several factors can influence student learning outcome.

Many teaching approaches have been attempted to improve learners' achievement especially in science-related subjects (Savelsbergh et al., 2016). For example, "problem-solving approach" strives to promote learners' active engagement in the learning process (Sikoyo, 2010) as well as demonstration and discussion teaching methods as used by Auwal (2013) to test students' retention of a specific science subject knowledge. Auwal further states that "what students learn is greatly influenced by how they are taught" (p. 63). It is thus the responsibility of a teacher to use the methods that best fit his or her learners in order to promote a democratic and meaningful learning for the learners. Moreover, Lattimer (2015) caution that in refining our understanding of the concept learner-centred education, we should not just focus on theoretical dialogues with researchers and policy makers but must also look closely at the work of implementers in order to clarify how theory might be translated into practice.

\section{Conclusion and Recommendations}

Based on the study findings, it can be concluded that the learner-centred approaches have an effect on the performance of the high school learners in a positive way; as the t-test results revealed a significant difference in learners' performance when they were taught using learner-centred approaches. Therefore, the results revealed that the final test (post-test) scores of the learners in the experimental group were higher compared to the control group. The experimental group was exposed to teaching methods that were more learner-centred and they provided what Viorica-Torii (2015: p. 1947) called "responsible learning by capitalizing student-centred strategies". For example, the mean scores of the experimental group increased from 11.9250 in the pre-test to 16.500 in the post-test; that is a difference of 4.575 . This means more learners have scored better marks in the post-test after the intervention. Moreover, the mode scores of this experimental group also changed from 11 to 15 . This means the results of the post test had more participants scoring 15 marks out of 20 comparing to 11 marks out of 20 in the pre-test Therefore, it can be concluded that the use of learner-centred approaches improves high school learners performance in understanding the topic Acids and bases in Physical Science Ordinary level. In this study, learner-centred approaches were effective in teaching acids and bases, as it helped learners to learn better and enhance their performance in acids and bases than the teacher-centred approaches. However, the authors are also aware that other external factors could have contributed to the learners' performance; therefore these results could not be generalized except if the subjects are having the same characteristics as those used in this study. On the other hand, the control group had the same mean scores in both the pre- and post-test (e.g., 11.200 mean scores). This could mean that the teacher-centred approaches caused little improvement in learners' performance. According to Jalani \& Sern (2015), 
teacher-centred learning mostly involves unnecessary activities that might trigger extraneous cognitive load and this might deteriorate learning.

The study therefore recommends that Physical Science teachers should make the teaching and learning of the topic acids and bases more practical-based by using learner-centred approaches such as practicals and experimentations, field trips, simulations, group work, just to mention but a few. Further study implications will be the promotion of learner-centred educational methods in the pre-service training programs of teachers at colleges and higher institutions of learning so that teachers get exposed to these methods during teacher-training courses.

\section{Acknowledgements}

Our greatest appreciation goes to Ohangwena Education Directorate, for the financial support rendered in carrying out this study. We also want to thank the Ministry of Education, Arts and Culture; the Permanent Secretary; and the Ohangwena Education Director who gave us permission to make use of the two selected secondary schools. To the principals of the two schools, the Physical Science teachers, the learners of the selected schools, thank you for your participation in this study.

\section{References}

Al-Zu'be, A. F. M. (2013). The Difference between the Learner-Centred Approach and the Teacher-Centred Approach in Teaching English as a Foreign Language. Educational Research International, 2, 24-31.

Auwal, A. (2013). Effects of Teaching Method on Retention of Agricultural Science Knowledge in Senior Secondary Schools of Bauchi Local Government Area, Nigeria. International Journal of Science and Technology Educational Research, 4, 63-69.

Baeten, M., Kyndt, E., Struyven, K., \& Dochy, F. (2010). Using Student-Centred Learning Environments to Stimulate Deep Approached to Learning: Factors Encouraging or Discouraging Their Effectiveness. Educational Research Review, 5, 243-260. http://www.Elsevier.com/locate/EDUREV https://doi.org/10.1016/j.edurev.2010.06.001

Bajah, S. T., \& Asim, A. E. (2002). Construction and Science Learning Experimental Evidence in a Nigerian Setting. World Council for Curriculum and Instruction (WCCI) Nigeria, 3, 105-114.

Bennett, J., Lubben, F., Hogarth, S., \& Campbell, B. (2004). A Systematic Review of the Use of Small-Group Discussions in Science Teaching with Students Aged 11-18, and Their Effects on Students' Understanding in Science or Attitude to Science. Research Evidence in Education Library.

Biggs, J. (1999). What the Student Does: Teaching for Enhanced Learning. Higher Education Research \& Development, 18, 57-75. https://doi.org/10.1080/0729436990180105

Boyadzhieva, E. (2016). Learner-Centred Teaching and Learner Autonomy. Procedia-Social and Behavioral Sciences, 232, 35-40. http://www.sciencedirect.com https://doi.org/10.1016/j.sbspro.2016.10.008

Boyle, B., \& While, D. (2004). A Longitudinal Study of Teacher Change: What Makes Professional Development Effective? Curriculum Journal, 15, 45-68.

https://doi.org/10.1080/1026716032000189471 
Brandes, D., \& Ginnis, P. (1996). A Guide to Student-Centred Learning. Nelson Thornes.

Bruce, J., \& Marsha, W. (1996). Models of Teaching. 5th Edition, Boston: Allyn and Bacon.

Cook, E. D., \& Hazelwood, A. C. (2002). An Active Learning Strategy for the Classroom- "Who Wants to Win... Some Mini Chips Ahoy?" Journal of Accounting Education, 20, 297-306.

Cros, D., Amouroux, R., Leber, J., \& Fayol, M. (2006). Conceptions of First-Year University Students of the Constituents of Matter and the Notions of Acids and Bases. European Journal of Science Education, 8, 305-315. https://doi.org/10.1080/0140528860080307

Cullingford, C. (1998). The Effective Teacher. London: Cassell Publisher.

Department of Education (2014). Education Statistics in South Africa at a Glance. Pretoria.

Directorate of National Examinations and Assessments (DNEA) (2013). Examiner's Report: Physical Science NSSCO. Windhoek: DNEA.

Doyle, T. (2008). Helping Students Learn in a Learner-Centred Environment: A Guide to Facilitating Learning in Higher Education. Stylus Publishing, LLC.

Driver, R., Guesne, E., \& Tiberghien, A. (1985). Some Features of Children's Ideas and Their Implications for Teaching. Children's Ideas in Science, 193-201.

Dunne, R., \& Wragg, T. (1997). Effective Teaching. London: Routledge.

Engelbrecht, F. (2000). General Teaching Methodology. Windhoek: Centre for External Studies, University of Namibia.

Froyd, J., \& Simpson, N. (2008). Student-Centred Learning Addressing Faculty Questions about Student Centred Learning. In Course, Curriculum, Labour, and Improvement Conference (Vol. 30, No. 11). Washington DC.

Goodwin, W. L., \& Goodwin, L. D. (1996). Understanding Quantitative and Qualitative Research in Early Childhood Education (Vol. 59).Teachers College Press.

Gray, A. (1997). Constructivist Teaching and Learning. SSTA Research Centre Report, 97-07.

Gredler, M. E. (1996). Educational Games and Simulations: A Technology in Search of a (Research) Paradigm. Technology, 39, 521-540.

Hailikari, T., Katajavuori, N., \& Lindblom-Ylanne, S. (2008). The Relevance of Prior Knowledge in Learning and Instructional Design. American Journal of Pharmaceutical Education, 72, 113. https://doi.org/10.5688/aj7205113

Hogan, K. (1999). Relating Students' Personal Frameworks for Science Learning to Their Cognition in Collaborative Contexts. Science Education, 83, 1-32. https://doi.org/10.1002/(SICI)1098-237X(199901)83:1<1::AID-SCE1>3.0.CO;2-D

Hua, Z., Harris, A. \& Ollin, R. (2011). Student Autonomy and Awareness: Vocational Education and Student-Centred Learning in China. Journal of Vocational Education and Training, 63, 191-203. https://doi.org/10.1080/13636820.2011.566346

Imasiku, S. (1999). Enviroteach's Approach to Learner-Centred Teaching Techniques. Enviroteach Co-Ordinator. Reform Forum, 9, 1-5.

Jalani, N. H., \& Sern, L. C. (2015). Efficiency Comparison between Example-ProblemBased Learning and Teacher-Centred Learning in the Teaching of Circuit Theory. Procedia-Social and Behavioral Sciences, 204, 153-163.

Johnson, C., \& McCoy, L. P. (2011). Guided Discovery Learning with Collaborative Discourse. Studies in Teaching 2011 Research Digest, 43.

Johnson, D. W., Johnson, R. T., Holubec, E., \& Roy, P. (1993). Circles of Learning. Edina: 
Inter-Action Book Company.

Jones, K. (1985). Designing Your Own Simulations. Abingdon-on-Thames: Taylor \& Francis.

Kagan, S. (1995). We Can Talk: Cooperative Learning in the Elementary ESL Classroom. ERIC Digest.

Kalpana, T. (2014). A Constructivist Perspective on Teaching and Learning: A Conceptual Framework. International Research Journal of Social Sciences, 3, 27-29.

Katz, L. G. (1990). The Case for Mixed-Age Grouping in Early Education. National Association for the Education of Young Children, 1834 Connecticut Avenue, NW, Washington, DC 20009-5786 (NAEYC Publication No. 333).

Khoboli, B. (2007). Doable Model of Learner-Centred Education: The Science Teachers' Product after a Twentieth Century Action Research. In I. Mutimucuio, \& M. Cherinda (Eds.), Proceedings of the 15th Annual Conference of the Southern African Association for Research in Mathematics, Science, and Technology Education (pp. 402-410). Mozambique: Eduardo Mondlane University Press.

Kolb, D. (1984). Experiential Learning as the Science of Learning and Development. Englewood Cliffs NPH.

Kyriacou, C., Manowe, B., \& Newson, G. (1999). Active Learning of Secondary School Mathematics in Botswana. Curriculum, 20, 125-130.

Lattimer, H. (2015). Translating Theory into Practice: Making Meaning of Learner Centred Education Frameworks for Classroom-Based Practitioners. International Journal of Educational Development, 45, 65-76. http://www.elsevier.com/locate/ijedudev

Lester, N., \& Onore, C. S. (1990). Learning Change: One School District Meets Language across the Curriculum. MacMillan.

McCombs, B. L., \& Whisler, J. S. (1997). The Learner-Centered Classroom and School: Strategies for Increasing Student Motivation and Achievement. The Jossey-Bass Education Series. San Francisco, CA: Jossey-Bass Inc.

McNeil, L. (1986). Contradictions of Control: School Structure and School Knowledge. New York, NY: Routledge.

Marioara, L. (2015). The Education Change for in Need Student-Centred Learning. Procedia-Social and Behavioral Sciences, 191, 2342-2345. http://www.sciencedirect.com

Martins, O. O., \& Oyebanji, P. K. (2000). The Effects of Inquiry and Lecture Methods on the Cognitive Achievement of Integrated Science Students. Journal of Science Teachers' Association, 35, 31-35.

Ministry of Education and Culture (MEC) (1993). Education for All. Windhoek, Namibia: Gamsberg.

Murphy-Graham, E. (2008). Opening the Black Box: Women's Empowerment and Innovative Secondary Education in Honduras. Gender and Education, 20, 31-50. https://doi.org/10.1080/09540250701650623

Nakhleh, M. B., \& Krajcik, H. (2004). Students' Model of Matter in the Context of Acids-Base Chemistry. Journal of Chemistry Education, 71, 495-499. https://doi.org/10.1021/ed071p495

Qhobela, M., \& Moru, E. K. (2011). Teaching Argumentation in Learning Physics at Secondary School Level in Lesotho: A Feasible Teaching Strategy. African Journal of Research in Mathematics, Science and Technology Education, 15, 97-111.

https://doi.org/10.1080/10288457.2011.10740713

Ramsden, P. (1992). Learning to Teach in Higher Education. London: Routledge. https://doi.org/10.4324/9780203413937 
Risse, T. (2004). Social Constructivism and European Integration.

Savelsbergh, E. R., Prins, G. T., Rietbergen, C., Fechner, S., Vaessen, B. E., Draijer, J. M., \& Bakker, A. (2016). Effects of Innovative Science and Mathematics Teaching on Student Attitudes and Achievement: A Meta-Analytic Study. Educational Research Review, 19, 158-172. http://www.elsevier.com/locate/ijedudev

Saville, B. K., Zinn, T. E., Neef, N. A., Norman, R. V., \& Ferreri, S. J. (2006). A Comparison of Inter-Teaching and Lecture in the College Classroom. Journal of Applied Behaviour Analysis, 39, 49-61. https://doi.org/10.1901/jaba.2006.42-05

Sikoyo, L. (2010). Contextual Challenges of Implementing Learner-Centred Pedagogy: The Case of the Problem-Solving Approach in Uganda. Cambridge Journal of Education, 40, 247-263. https://doi.org/10.1080/0305764X.2010.509315

Taber, K. S. (2011). Guiding the Practice of Constructivist Teaching. Teacher Development, 15, 117-122. https://doi.org/10.1080/13664530.2011.555229

Viorica-Torii, C. (2015). Reflections on the Development of Responsible Learning by Capitalizing Student-Centred Educational Strategies. Procedia-Social and Behavioral Sciences, 191, 1947-1951.

Vygotsky, L. S. (1978). Mind in Society: The Development of Higher Mental Process. Cambridge, MA: Harvard University Press.

Weimer, M. (2002). Learner-Centred Teaching: Five Key Changes to Practice. San Francisco, CA: Jossey-Bass.

Submit or recommend next manuscript to SCIRP and we will provide best service for you:

Accepting pre-submission inquiries through Email, Facebook, LinkedIn, Twitter, etc. A wide selection of journals (inclusive of 9 subjects, more than 200 journals)

Providing 24-hour high-quality service

User-friendly online submission system

Fair and swift peer-review system

Efficient typesetting and proofreading procedure

Display of the result of downloads and visits, as well as the number of cited articles

Maximum dissemination of your research work

Submit your manuscript at: http://papersubmission.scirp.org/

Or contact ce@scirp.org 